\title{
VISUALIZATION OF SCANTER AND ARPA RADAR DATA IN THE DISTRIBUTED TELEINFORMATION SYSTEM FOR THE BORDER GUARD
}

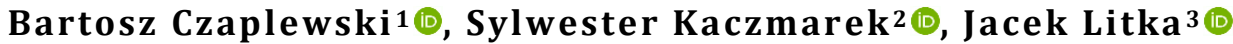

Gdansk University of Technology, Faculty of Electronics, Telecommunications and Informatics, Department of Teleinformation Networks, Narutowicza 11/12 Str., 80-233 Gdańsk, Poland, e-mail: bartosz.czaplewski@eti.pg.edu.pl, kasyl@eti.pg.edu.pl, jacek.litka@pg.edu.pl; ORCID ID: 10000-0001-7904-5567, 20000-0003-2932-5610, ${ }^{30000-0002-3538-4118 ~}$

\begin{abstract}
Monitoring of country maritime border is an important task of the Border Guard. This activity can be enhanced with the use of the technology enabling gathering information from distributed sources, processing of that information and its visualization. The paper presents the next stage of development of the STRADAR project (Streaming of real-time data transmission in distributed dispatching and teleinformation systems of the Border Guard), which is realized for the security and defence of the country. In the paper, storing, processing and visualization of the radar data, which is one of the tasks of the discussed scientific and research project, is described. Firstly, the general principle of radar data flow in the system was presented. Secondly, technical software description was described. Finally, radar data visualization functionality was presented.
\end{abstract}

Keywords:

border guard, radar data, surveillance, visualization, vessel traffic system.

Research article

(C) 2019 Bartosz Czaplewski, Sylwester Kaczmarek, Jacek Litka This is an open access article licensed under the Creative Commons Attribution-NonCommercial-NoDerivatives 4.0 license (http://creativecommons.org/licenses/by-nc-nd/4.0/) 


\section{INTRODUCTION}

The Border Guard has to be equipped with a technology enabling communication, acquisition, exchange and visualization of data in different operational situations. Currently the Polish Republic maritime border is monitored and supported by the Automatic National System of Radar Control for Maritime Areas of Poland (Zautomatyzowany System Radarowego Nadzoru Polskich Obszarów Morskich - ZSRN) which is an integrated security system [9]. This article is about a project that aims to remove the limitations of the solution currently in use.

The STRADAR project is dedicated to streaming real-time data in distributed teleinformation systems of the Border Guard. The project is implemented for the security and defence and it is funded by the National Centre for Research and Development. The project is the extension of the KONSOLA $[6,7]$ project in which the Border Guard distributed map data exchange system have been developed. Currently, tactical information is collected from Mobile Units (vehicles, airplanes and vessels), Observation Points (OP) and web service. The scope of the information types includes AIS and ARPA radar data, telephone and radio calls, video (cameras), photos, files, SMS messages, map objects anomalies, and more. The STRADAR project allows for visualization of current or archival operational situation composed of any combination of synchronized data of the above types.

In this regard, the discussed system, or at least its fragment, can be considered as a Vessel Traffic Service (VTS) system utilizing combined AIS, ARPA, and GPS data. Studies on applications of AIS for VTS systems can be found in [10]. Other studies on operator situation awareness in VTS systems can be found in [11].

The STRADAR project has been extended and new goals for further development were established. One of these goals is the introduction of new functionality of storing, processing and visualization of SCANTER radar data alongside with ARPA data. This new functionality is not merely an addition of new type of data but it is the design of new interfaces, servers and database, along with the visualization familiar to the operator. These new functions are neither a replacement nor an enhancement of the current map data functions but they are independent, additional features. This paper describes these new features of the system.

The structure of the paper is as follows. Firstly, the general principle of radar data flow in the system was presented. Secondly, technical software description was described. Finally, functionality of radar data visualization was presented. The summary and the list of future work were discussed in the end of the paper. 


\section{RADAR DATA FLOW IN THE SYSTEM}

The structure of the STRADAR system is presented in fig. 1. and a simplified flow of the radar data is highlighted using dark grey blocks and bolded lines. The following elements can be distinguished within the system: central server (CS), archive servers (AS), event visualization post (EVP), telecommunications servers (TS), mobile units (MUs), observation points (OPs), stationary consoles, and web service. However, from the perspective of the radar data flow, telecommunications servers and web service are not relevant. All the components are connected via secure IP network of the Border Guard.

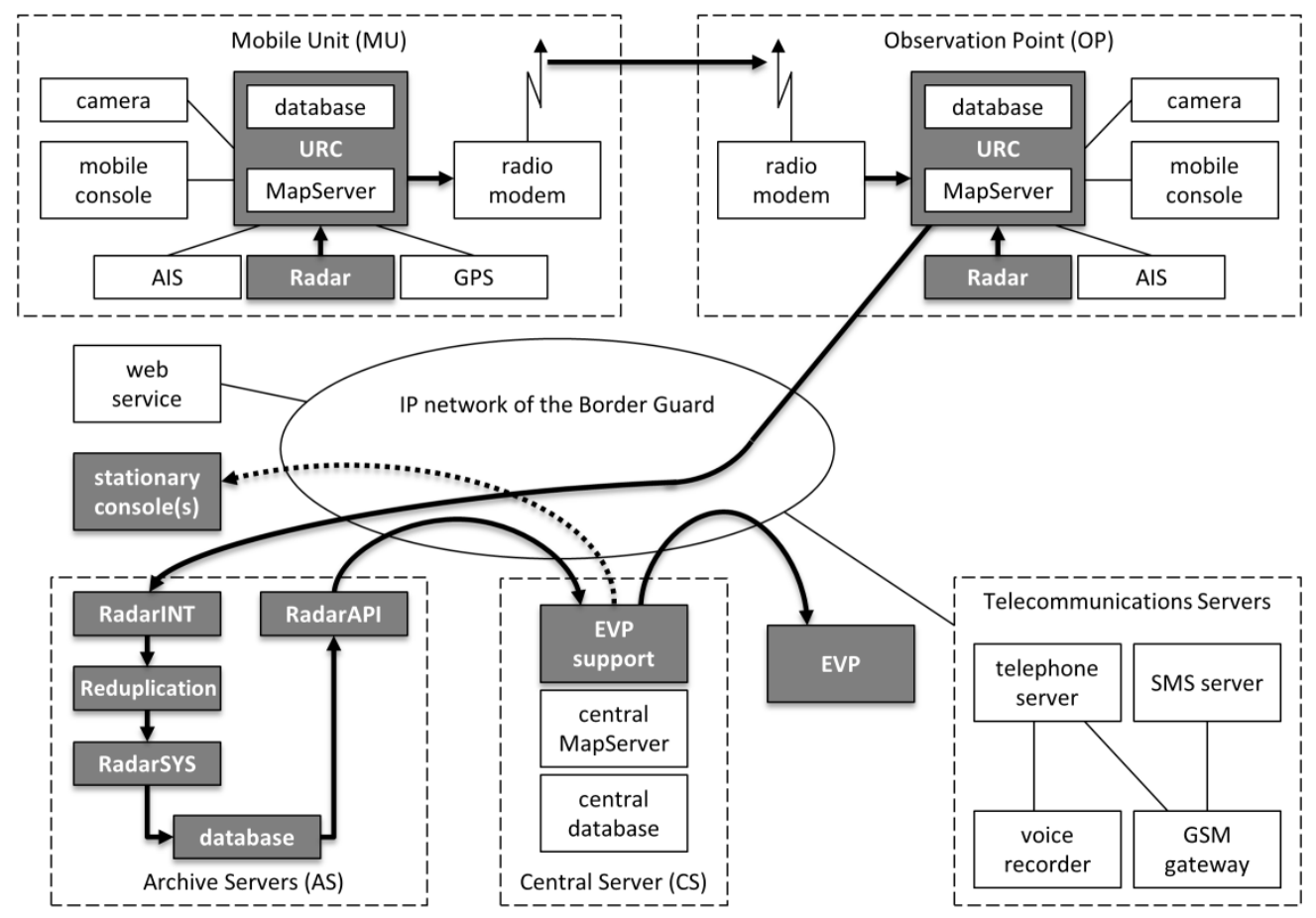

Fig. 1. A simplified flow of the radar data in the STRADAR system

The sources of radar data are ARPA and SCANTER radar devices providing data via dedicated video distribution and tracking (VDT) protocol through universal radio controllers (URC) on mobile units (MU) or observation points (OP). MU consists of mobile universal radio controller (URC), a mobile console, a camera, AIS receiver, ARPA radar device, GPS device and radio modem. OP consists of stationary URC, an optional mobile console, a camera, AIS receiver, SCANTER radar device, and 
radio modem. URC contains local map server and local database. The functionality of the URC is gathering data from a remote range, sending the data to the CS for synchronization, retrieving the data from the CS on demand, and more. URC is implemented as a proprietary DGT hardware solution which is based on the Marvell Armada processor. The functionality of the mobile console is the same as for the stationary console. Mobile console is implemented as Getac V200 fully rugged convertible notebook.

Radar data is collected within the AS, which provides separate databases for radar data, video recordings, audio recordings, SMS messages, files/images. The functionality of the AS is storing and searching data on the basis of sophisticated criteria, fragmenting and defragmenting video streams for fast and on demand video creation, adding text notes, providing data for EVP, retrieving streams from cameras, and more. AS has been implemented on Dell R510 dedicated server devices using cloud computing and elastic search technology with Debian Linux operating system. In the context of radar data flow, the AS consists of the following modules: interfaces for incoming radar data (RadarINT), reduplication (fusion) module, system module (RadarSYS), and interfaces for visualization (RadarAPI). These elements store data in the AS database and save binary data in the AS server file system. The transmission of messages takes place via a queuing system or via web services in accordance with the RESTful API architecture. RadarINT is responsible for establishing and maintaining connection with data sources, initial validation of data, and transferring data for further processing. The reduplication (fusion) module is responsible for detecting duplicates of objects from various sources and combining them in an automated manner. RadarSYS is responsible for writing records to the database about new vessels and supplementing data on existing ones. RadarAPI is responsible for interpretation of requests, searching radar data according to given criteria, and formatting of responses for other system elements.

CS is the heart of the system and it contains central map server, database for AIS, ARPA, GPS, and web service data on naval objects (however, it is an independent, additional base in relation to the base in AS), and EVP support. The functionality of the CS is gathering map data from all the sensors, reduplication (fusion) of the gathered data, collecting visualization tasks from all the sources, map object anomaly detection, intermediation of access to AS, providing data for EVP, and more. CS has been implemented and running on NTT Tytan 1204 S83 Advanced dedicated server device with 64-bit Debian Linux operating system. From the perspective of the functionality presented in this paper, the only relevant role of the CS is intermediation of access to AS and providing data for EVP. 
EVP is the main client of the system and it consists of PC, a standard monitor for management, and a multidisplay screen built from multiple monitors for visualization. The functionality of the EVP is visualization of events using map data, files/images, SMS messages, audio recording, and video recordings, visualization of data with or without time synchronization, generation of visualization tasks, handling of reported visualization tasks, browsing through metadata retrieved from AS via CS, browsing through map object anomalies, adding text notes, and more. EVP has been implemented as C\# .NET (framework 4.0) application for 64-bit MS Windows system. In the context of the radar data flow, EVP consumes the data via MapControl, which is the software for visualization of data on the digital maps.

Stationary console is a communication device with a touch screen and a headset. The functionality of the stationary console is establishing and receiving voice calls using the TS, sending and receiving SMS messages using the TS, visualization of data on digital maps using the CS, browsing through data on naval objects using the CS, sending files/images to the AS, generation of visualization task to the CS, browsing through map object anomalies using the CS, and more. Stationary console is implemented as DGT5810-10 dispatcher console. In the context of the radar data flow, stationary consoles optionally consume the data via MapControl.

More details on particular components of the STRADAR system have been already published in [1-6, 8].

\section{TECHNICAL SOFTWARE DESCRIPTION}

The software for the visualization of SCANTER and ARPA radar data was written in C\# language using .NET 4.0 framework. The software, named MapControl, was implemented in a form of UserControl of the C\# language, and embedded within two C\# applications. First on them is the EVP, and the second is console dispatcher application running both on stationary and mobile consoles. Both applications are designed for 32-bit or 64-bit MS Windows systems.

\section{FUNCTIONALITY OF RADAR DATA VISUALIZATION}

MapControl, which was software started in the earlier stage of the project, has been extended to visualize SCANTER and ARPA data from the AS. The scope of work of this extension included, among others:

- creation of a new dynamic layer of objects for ARPA and SCANTER data;

- formatting new requests and interpreting new responses for data from AS;

3 (218) 2019 
- distinguishing data due to the servers from which they originate;

- enlarging the set of configuration parameters for correct operation;

- optimization of the request sending scheme based on performance tests;

- optimization of the visualization mechanisms of the travelled routes;

- adding text notes to vessels on the map;

- adding operational names to vessels on the map;

- changes in the GUI.

An example of visualization of current radar objects is shown in fig. 2. An example of a panel with detailed information about a radar object is shown in fig. 3 . The visualization of travelled routes of radar objects is shown in fig. 4. Ultimately, the full functionality of radar data visualization on digital maps using the MapControl software is listed below.

1. Rendering of digital maps:

- displaying layers of digital maps of multiple formats (e.g. S-57);

- adding and removing map layers (cells) while the software is running;

- configuration of visibility of displayed map sublayers;

- presentation of the map scale relative to the current approximation;

- presentation of the north direction relative to the used coordinate system.

2. Geographic coordinate system:

- selection of any projection of coordinates according to the EPSG code;

- selection of any projection of coordinates by name.

3. Geographic coordinates format:

- displaying coordinates in DMS format;

- displaying coordinates in DD format;

- displaying coordinates in the native format of the map.

4. Panning the observed part of the map:

- moving the area with the buttons;

- moving the area by dragging the cursor;

- centering the area at given coordinates;

- centering the area on URC's coordinates (if known);

- centering the area on the selected vessel on the map.

5. Zooming the observed part of the map:

- zooming in and out with the buttons;

- zooming in and out of the area by selecting a part of the map;

- zooming in and out of the area by dragging the cursor;

- setting the full view of all loaded maps. 
6. Downloading data:

- downloading data from a MapServer (AIS, ARPA, GPS, web service);

- downloading data from Archive Servers (SCANTER, ARPA);

- downloading data from CS on demand even then running on MU.

7. Presentation of graphic symbols of objects (example in fig. 2):

- presentation of graphic symbols based on type and category of the object;

- presentation of normalized course vectors at the symbols of objects;

- optional alternative presentation of ship outlines according to their course.

8. Presentation of text labels of objects (example in fig. 2):

- managing of non-overlapping locations of text labels;

- prioritization of data displayed in text labels.

9. Object filtering:

- filtering graphic symbols of unidentified objects;

- filtering graphic symbols based on type or category of the object;

- filtering text labels of unidentified objects;

- filtering text labels based on type or category of the object.

10. Detailed object information panels (example in fig. 3):

- opening detailed information panels by selecting an object on the map;

- managing of non-overlapping locations of detailed information panels;

- enabling centering on the object;

- enabling visualization of traveled route of the object;

- enabling tracking the selected object;

- adding and presenting text notes corresponding to the object;

- adding the operational name to the object.

11. Presentation of the traveled routes (example in fig. 4):

- drawing the traveled routes to the dynamic layers of objects;

- enabling visualization of traveled routes for any number of objects;

- enabling visualization of traveled routes for all the objects;

- changing the presented length of the routes, from 15 to 120 minutes.

12. Playback of archival situations on the map:

- displaying the archival situation from the given date and time;

- change in the playback speed of the archival situation;

- presentation of graphic symbols as for the current situation (see 7);

- presentation of text labels of objects as for the current situation (see 8);

- object filtering as for the current situation (see 9);

- detailed object information panels as for the current situation (see 10);

- presentation of the traveled routes as for the current situation (see 11).

3 (218) 2019 


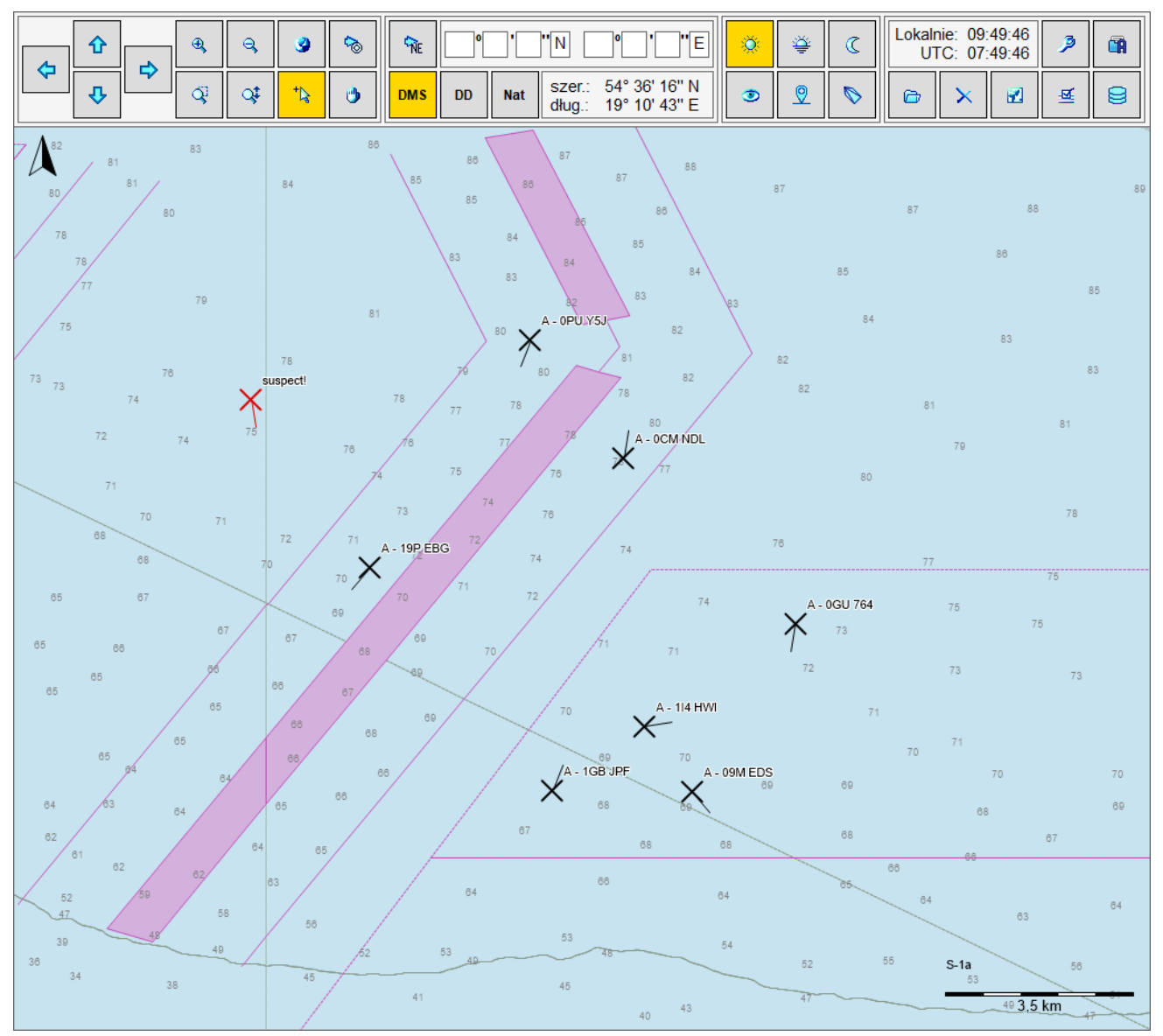

Fig. 2. An example of visualization of current radar objects (testing data)

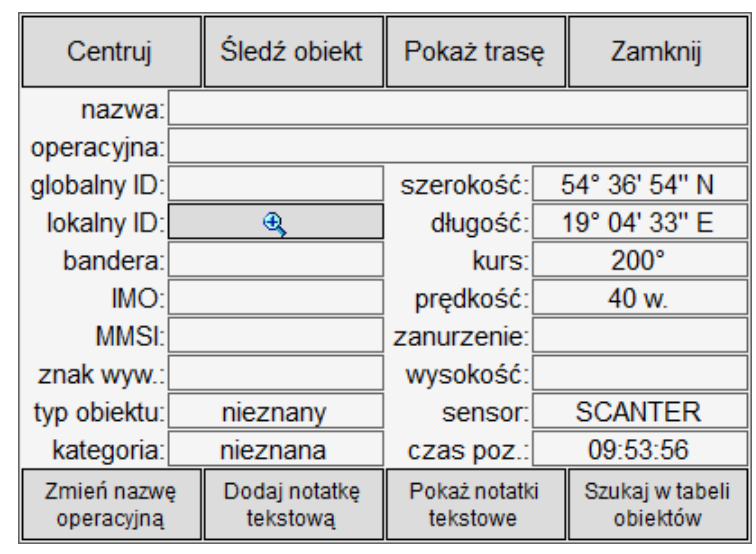

Fig. 3. A panel with an example of detailed information about a radar object (testing data) 


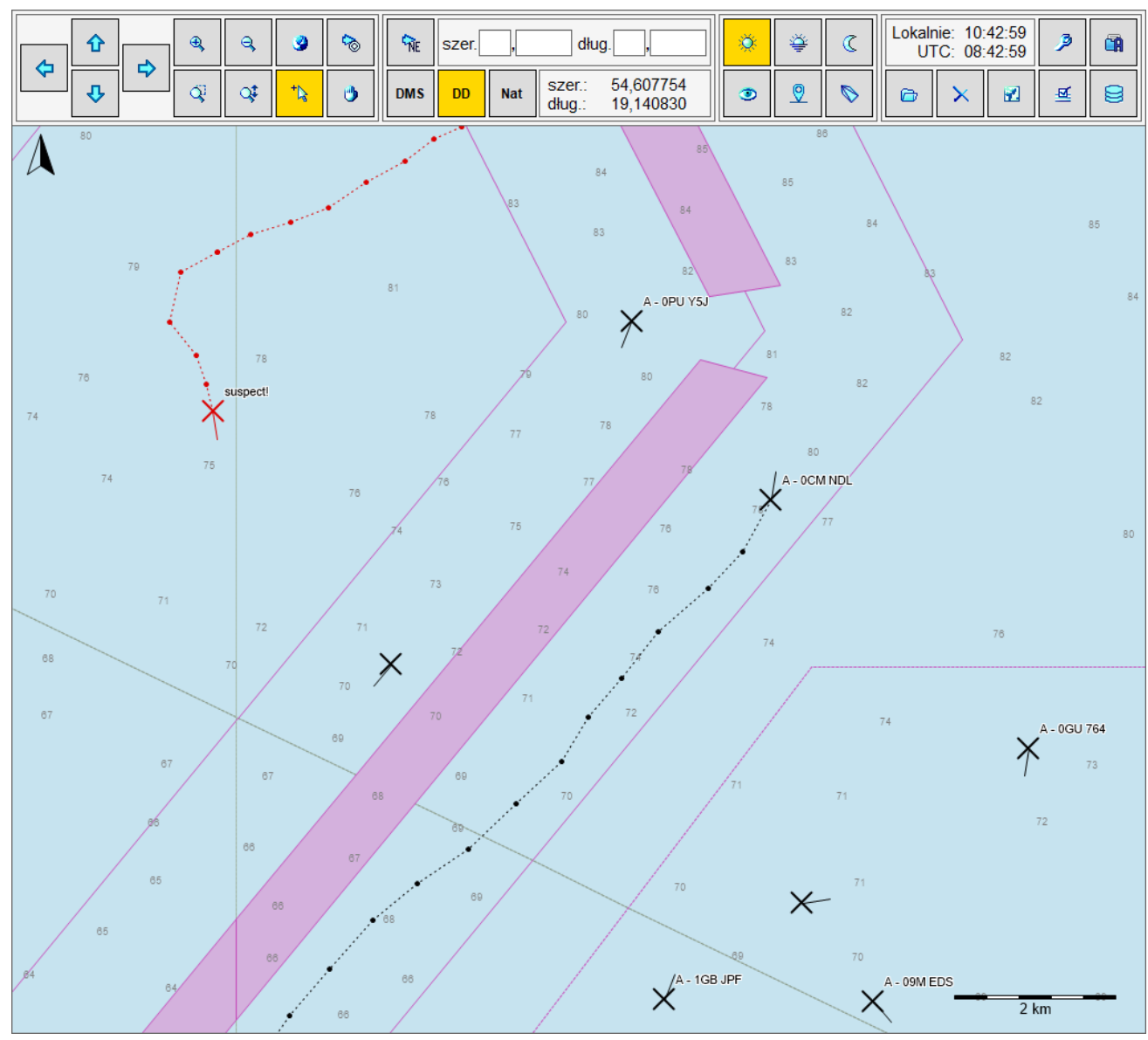

Fig. 4. An example of the visualization of travelled routes of radar objects (testing data)

13. Color variants for GUI:

- 'day' color variant for map layers;

- 'dusk' color variant for map layers;

- 'night' color variant for map layers;

- 'day' color variant for symbols and labels of objects;

- 'dusk' color variant for symbols and labels of objects;

- 'night' color variant for symbols and labels of objects.

14. Time presentation:

- presentation of the date and time in local time;

- presentation of the date and time in UTC time.

15. Configuration saving. 
16. Interface to the console dispatcher application.

17. Interface to the Events Visualization Post application.

\section{SUMMARY}

The paper presents the next stage of development of the STRADAR project (Streaming of real-time data transmission in distributed dispatching and teleinformation systems of the Border Guard), which is realized for the security and defense of the country. Firstly, the general principle of radar data flow in the system was described. Secondly, technical software description was presented. Finally, radar data visualization functionality was listed.

The implementation of the radar data flow brought new challenges, e.g. among others designing new protocols, new message structures, new modules in both servers and visualization tools, new test data sources, i.e. scanter radar emulator, and the expansion of existing software. Each of the discussed system elements have been implemented separately and tested on both static and emulated data. Currently, integration works are in place and the final product will be complete at the end of 2019.

Visualization of Scanter and ARPA radar data is only one of many objectives of the project. The other tasks of this stage of the project are as follows: video camera control services compatible with the ONVIF standard, device management services, user management services, transformation of URC and EVP to the 9th level of technology.

\section{Acknowledgments}

This work has been co-financed by NCBiR (National Center for Research and Development), project DOB-BI06/10/62/2014.

\section{REFERENCES}

[1] Blok M., Czaplewski B., Kaczmarek S., Litka J., Narloch M., Sac M., STRADAR - Multimedia Dispatcher and Teleinformation System for the Border Guard, 'Scientific Journal of Polish Naval Academy', 2019, Vol. 2016, No. 1, pp. 69-89, DOI: 10.2478/sjpna-2019-0006.

[2] Blok M., Czaplewski B., Kaczmarek S., Litka J., Narloch N., Sac M., Streaming real-time data in distributed dispatcher and teleinformation systems for visualization of multimedia data of the border guard, 'TransNav, International Journal on Marine Navigation and Safety of Sea Transportation', 2018, Vol. 12, No. 2. 
[3] Blok M., Czaplewski B., Kaczmarek S., Młynarczuk M., Narloch M., Sac M., Multimedia distributed system for visualization of ongoing and archival events for BG, VII Int. Conf. NATCON 2016, Chapter 6, pp. 61-76.

[4] Blok M., Kaczmarek S., Młynarczuk M., Narloch M., MapServer — information flow management software for the Border Guard distributed data exchange system, 'Polish Maritime Research', 2016, Vol. 91 (3), pp. 13-19.

[5] Czaplewski B., Blok M., Kaczmarek S., Narloch M., Performance Measurements and Optimization of Visualization of Routes Traveled in the Distributed Dispatcher and Teleinformation System for Visualization of Multimedia Data for the Border Guard, The European Navigation Conference (ENC 2019), 9-12 April, Warsaw 2019.

[6] Czaplewski B., Cwalina K., Blok M., Kaczmarek S., Miszewski M., Młynarczuk M., Sac M., A system of visualization of operational situation on digital maps for mobile units of the Border Guards, VII Int. Conf. NATCON 2016, Chapter 5, pp. 51-60.

[7] Czaplewski B., Cwalina K., Kaczmarek S., Katulski R., Data visualization of marine objects on digital maps, 'Scientific Journal of Polish Naval Academy', 2015, Vol. 202, No. 3, pp. 5-13, D0I: 10.5604/ 0860889X.1178566.

[8] Czaplewski B., Kaczmarek S., Litka J., Miszewski M., Visualization of events using various kinds of synchronized data for the Border Guard, 'Scientific Journal of Polish Naval Academy', 2017, Vol. 209, No. 2, pp. 5-13, DOI: DOI: 10.5604/01.3001.0010.4059.

[9] Fiorini M., Maciejewski S., Lesson Learned During the Realization of the Automated Radar Control System for Polish Sea-waters (ZSRN), Marine Navigation and Safety of Sea Transportation: Advances in Marine Navigation, CRC Press, 2013, pp. 217-221.

[10] Tetreault B. J., Use of the Automatic Identification System (AIS) for maritime domain awareness (MDA), Proc. MTS/IEEE OCEANS' 05, 2005.

[11] Wiersma J. W. F., Assessing Vessel Traffic Service Operator Situation Awareness, PhD thesis, Delft University of Technology, Oisterwijk 2010.

\section{WIZUALIZACJA DANYCH RADAROWYCH SCANTER ORAZ ARPA \\ W ROZPROSZONYM SYSTEMIE TELEINFORMACYJNYM DLA STRAŻY GRANICZNEJ}

\section{STRESZCZENIE}

Monitorowanie krajowej granicy morskiej jest ważnym zadaniem Straży Granicznej. Działanie to można wzmocnić za pomocą technologii umożliwiającej gromadzenie informacji z rozproszonych źródeł, przetwarzanie tych informacji i ich wizualizację. Artykuł przedstawia kolejny etap rozwoju projektu STRADAR. Omówiono w nim jedno z zadań projektu naukowo-badawczego, którym jest przechowywanie, przetwarzanie i wizualizacja danych radarowych. Przedstawiono ogólną zasadę 
przepływu danych radarowych w systemie, następnie przedstawiono techniczny opis oprogramowania oraz zaprezentowano funkcjonalność wizualizacji danych radarowych.

\section{Słowa kluczowe:}

autonomiczny pojazd podwodny, biomimetyczny autonomiczny pojazd podwodny, regulacja kursu i głębokości, sterowanie autonomiczne.

Article history

Received: $\quad 05.06 .2019$

Reviewed: 28.08.2019

Revised: $\quad 03.09 .2019$

Accepted: $\quad 04.09 .2019$ 